\title{
The control of septum formation in fission yeast
}

\author{
Kathleen L. Gould ${ }^{1,3}$ and Viesturs Simanis ${ }^{2,3}$ \\ ${ }^{1}$ Howard Hughes Medical Institute and Department of Cell Biology, Vanderbilt University School of Medicine, $\mathrm{N}$ ashville, \\ Tennessee 37232 USA; ${ }^{2}$ Swiss Institute for Experimental Cancer Research, 1066 Epalinges, Switzerland
}

If cell division is to produce two daughter cells that are viable, faithful copies of the parent cell, the landmark events of the cell division cycle, S phase, mitosis, and cytokinesis, must be executed in the correct order and with high fidelity. Though considerable advances have been made toward understanding the mechanisms that control the onset of $\mathrm{S}$ phase and mitosis, regulation of the events that occur at the end of the cell cycle, such as the reorganization of the cytoskeleton and the initiation of cell separation or cytokinesis, are less well understood. The fission yeast Schizosaccharomyces pombe provides a simple eukaryotic model for the study of cytokinesis. S. pombe cells are rod shaped, grow mainly by elongation at their ends, and divide by binary fission after forming a centrally placed division septum. Study of S. pombe mutants has begun to shed light on how septum formation and cytokinesis are regulated both spatially and temporally, to achieve proper co-ordination with mitosis. Some of the genes defined by these mutants have been functionally conserved through eukaryotic evolution, suggesting that aspects of this control will be common to all eukaryotic cells.

\section{Septum formation and cytokinesis in the fission yeast S. pombe}

The main morphological events of septum formation and cytokinesi s in S. pombe are shown in Figure 1. As in higher eukaryotes, the fission yeast cytoskel eton undergoes a characteristic series of rearrangements during mitosis and cytokinesis (for review, see Robinow and $\mathrm{Hy}$ ams 1989). The distribution of F-actin in S. pombe cells is linked intimately with sites of growth and septum formation. During interphase, F-actin is observed mainly as cortical patches at the growing ends of the cell, though actin cables can also be seen (M arks and Hyams 1985; Balasubramanian et al. 1996). Structural studies of cortical actin have demonstrated that it is composed of spiral actin filaments that are associated with an invagination of the plasma membrane (Mulholland et al. 1994). During the early stages of mitosis, before any visible

\footnotetext{
${ }^{3}$ Correspondence may be directed to either author.

E-MAIL gouldk@ctrvax.vanderbilt.edu; FAX (615) 343-4539.

E-MAIL viesturs.simanis@isrec.unil.ch; FAX +41-21-652-6933.
}

chromosome separation, a structure called the medial ring forms at the center of the cell, overlying the nucleus. The position of this ring anticipates the site of septum formation. This ring is composed of F-actin and many other components (see below). F-actin patches are subsequently polarized to the medial ring, and the cell is thus primed for septation. At the end of anaphase, when the spindle begins to break down, biosynthesis of the septum is initiated, and the primary septum grows inward from the cell cortex (Johnson et al. 1973). As its biosynthesis proceeds, it is surrounded by F-actin patches ( $M$ arks and Hyams 1985), and a ring of F-actin is seen at its leading edge (Jochová et al. 1991). In electron micrographs, F-actin filaments are seen between the edges of the developing septum (Kanbe et al. 1989). The completed septum has a three-layered structure, composed of the inner, primary septum, flanked by the two secondary septa. The primary septum can be visualized by Calcuofluor staining. Fission begins by degradation of the outer cell wall opposite the site of the completed septum and is completed by centripetal degradation of the primary septum to bring about cell separation (Johnson et al. 1973). At this time, the F-actin patches are relocated to the old (pre-existing) end of the cell, from where growth will resume.

S. pombe mutants defective in septum formation
or cytokinesis

One of the considerable advantages of a simple model system, such as yeast, is that genes that encode proteins important for the regulation or execution of complex processes can be identified through the study of mutants. A small number of heat-sensitive, cell-division-defective mutants were identified in early screens (e.g., N urse et al. 1976). Recently, the mutant set has been expanded considerably by the use of a method involving selection for cells that increase ploidy (e.g., Chang et al. 1996). Originally designed to enrich for mutants that rereplicated their DN A, this elegant screen is based on the use of cells that cannot mate but are able to undergo meiosis if they are able to di pl oidize by other means (Broek et al. 1991). This can occur by rereplication of DN A, by failure to separate the daughter chromosomes before septation, or by failure to synthesize, or correctly position, the di- 
vision septum. The two latter classes increase in ploidy by having two nuclei in the same cytoplasm. Thus, the screen enriches for mutants defective in septum formation. The foll owing sections describe some $\mathrm{S}$. pombe cell cycle mutants that show terminal phenotypes indicating that they are unable to execute events important for one or more of the stages in septum formation and cell cleavage described in Figure 1. They are listed in Table 1, and a schematic representation of some of the phenotypes produced by loss-of-function mutations in these genes is shown in Figure 2.

\section{Nomenclature}

The original report of fission yeast cell cycle mutants described two categories of septation mutants, called "early" and "late" (N urse et al. 1976). Early mutants were those that failed to make a septum at all, whereas late mutants arrested after forming a disorganized septum. This terminology assumed (logically enough) that early mutants were defective in an early event of septum formation, whereas late mutants were defective in an event after the initiation of septum biosynthesis. Subsequent analysis of the mutants and cloning of the genes they defined have demonstrated that this is not the case (see below). Therefore, this terminol ogy is not used. Furthermore, throughout this review, "medial ring," rather than "actin ring," is used to describe the structure formed at the cell cortex early in mitosis, because it contains many proteins in addition to actin.

\section{The medial ring}

Mutants defective in assembly of the medial ring

Analysis of mutants has shown that many components are involved in the assembly of the medial ring. These include actin (act1: Ishiguro and Kobayashi 1996; McCollum et al. 1996), type II myosin (myo2: Kitayama et al. 1997), profilin (cdc3: Balasubramanian et al. 1994), tropomyosin (cdc8: Balasubramanian et al . 1992), a myosin light chain-like protein (cdc4: M cCollum et al. 1995), a formin (cdc12: Chang et al. 1997), an SH3 domaincontaining protein (cdc15: Fankhauser et al. 1995; Chang et al . 1996), and the product of the rng2 gene (Chang et al. 1996), which has not been cloned to date. All of these genes are necessary for medial ring assembly. However, in addition to the lack of medial ring formation, mutant alleles of several of these genes retain residual activity at the restrictive temperature and display other aberrant phenotypes (see below). These additional abnormalities most likely reflect the protein's involvement in other actin-requiring processes.

Profilin is an ubiquitous actin monomer-binding protein. It was first purified in a 1:1 complex with actin and can sequester actin monomers under some conditions. However, profilin is now considered to be a critical mediator of actin filament polymerization (for review, see Theriot and Mitchison 1993; Sohn and GoldschmidtClermont 1994). The inability of Cdc3p mutants to form a medial ring (Balasubramanian et al. 1994) is consistent with a primary role for profilin in actin filament assembly. Profilin also binds tightly to polyproline and to proteins containing stretches of proline residues. Among the polyproline-containing proteins found to bind profilin in vitro is Cdc12p (Chang et al. 1997).

During interphase, Cdc3p local izes to the growing tips of the cells, where actin patches are concentrated, whereas Cdc $8 p$ is seen in discrete patches at the cell cortex. At mitosis, Cdc8p is found as a component of the medial ring, joining the ring after $\mathrm{F}$-actin (Bal asubramanian et al. 1992), whereas C dc3p forms a broad ring at the
Figure 1. Schematic representation of the main events of septum formation and cytokinesis in S. pombe. The nucleus is shown as a gray circle, whereas the small red dots represent F-actin patches. NETO is New End Take-Off (Mitchison and N urse 1985): Cells switch from one-end to two-end growth. The genes implicated in each of the stages are indicated. Grouping of genes does not necessarily imply that their products interact physically.

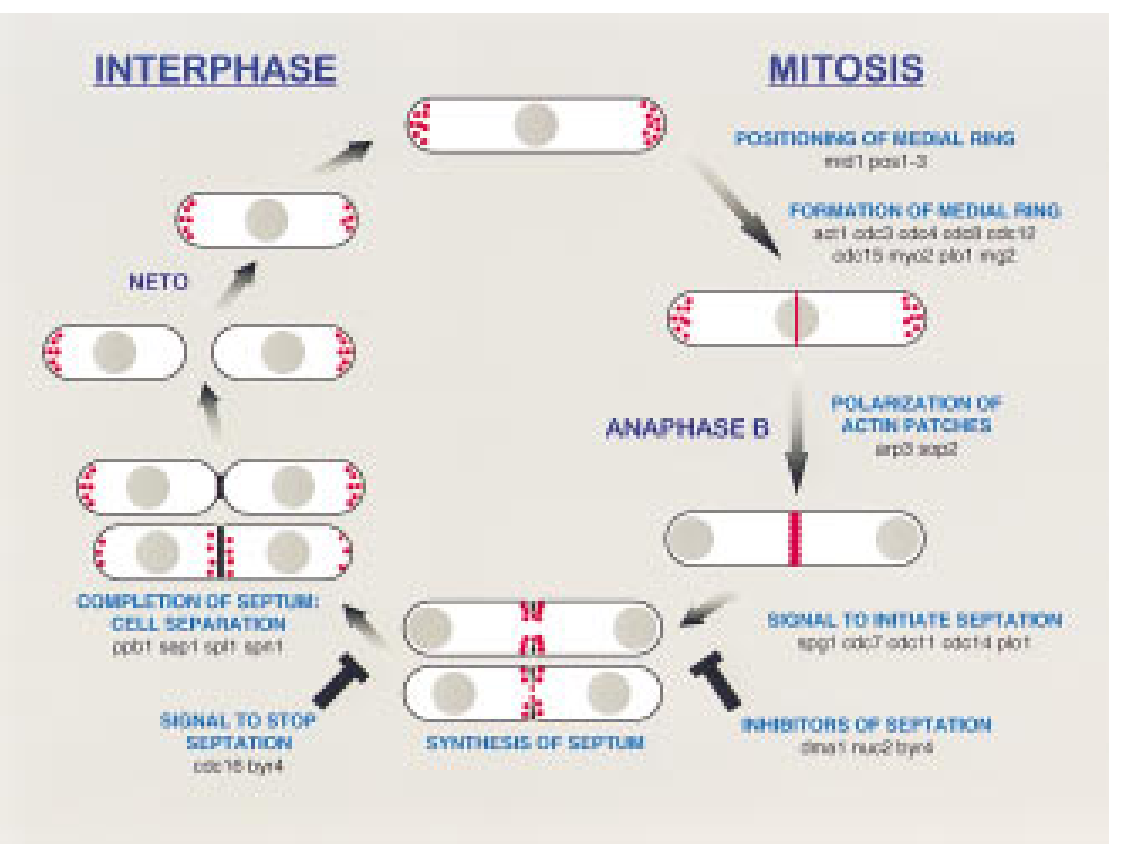


cell equator (Balasubramanian et al. 1994). Consistent with these localization patterns, mutants in cdc3 and cdc8 exhibit delocalized actin patches at all stages of the cell cycle, indicating that they are involved in the gen-

Table 1. Genes implicated in the control of septum formation in Schizosaccharomyces pombe

\begin{tabular}{|c|c|c|c|c|}
\hline Gene & Gene product & $\begin{array}{l}\text { Loss of } \\
\text { function phenotype }\end{array}$ & $\begin{array}{l}\text { Overproduction } \\
\text { phenotype }\end{array}$ & Comments \\
\hline \multicolumn{5}{|c|}{ Medial ring assembly } \\
\hline act1 & actin & $\Delta:$ lethal & lethal & \\
\hline cdc3 & profilin & $\begin{array}{l}\Delta: \text { lethal, no medial ring, no } \\
\text { septum } \\
\text { ts: gives a disorganized } \\
\text { septum, defective in } \\
\text { localization of actin } \\
\text { patches }\end{array}$ & $\begin{array}{l}\text { altered cell shape, lethal, } \\
\text { but rescued by } \\
\text { co-overproduction of actin } \\
\text { no discrete actin staining }\end{array}$ & $\begin{array}{l}\text { localizes to broad medial } \\
\text { band during mitosis, and } \\
\text { actin patches } \\
\text { double-lethal required for } \\
\text { localization of } C \text { dc12p and } \\
\text { Midlp, binds Cdc12p }\end{array}$ \\
\hline cdc4 & $\begin{array}{l}\text { EF hand protein (novel } \\
\text { myosin light chain) }\end{array}$ & $\begin{array}{l}\Delta \text { : lethal, no actin ring, no } \\
\text { septum } \\
\text { ts: actin cables, disorganized } \\
\text { septum. Cdc12p found as } \\
\text { a dot }\end{array}$ & lethal, blocks septation & $\begin{array}{l}\text { localizes to medial ring } \\
\text { required for Midlp ring } \\
\text { formation }\end{array}$ \\
\hline cdc8 & tropomyosin & $\begin{array}{l}\Delta: \text { lethal, no medial ring, no } \\
\text { septum } \\
\text { ts: gives a disorganized } \\
\text { septum, defective in } \\
\text { localization of actin } \\
\text { patches }\end{array}$ & $?$ & $\begin{array}{l}\text { localizes to medial ring, } \\
\text { required for localization of } \\
\text { Cdc12p and Midlp to the } \\
\text { medial ring }\end{array}$ \\
\hline $\operatorname{cdc} 12$ & $\begin{array}{l}\text { Diaphanous-like protein } \\
\text { Formin-homology } \\
\text { domains }\end{array}$ & $\begin{array}{l}\Delta: \text { lethal, no medial ring, no } \\
\text { septum } \\
\text { ts: gives a disorganized } \\
\text { septum, defective in } \\
\text { localization of actin } \\
\text { patches } \\
\text { ts: no medial ring }\end{array}$ & $\begin{array}{l}\text { lethal, dot of } \mathrm{Cdc} 12 \mathrm{p} \text { seen } \\
\text { between nucleus and } \\
\text { cortex }\end{array}$ & $\begin{array}{l}\text { localizes to medial ring, } \\
\text { required for Midlp ring } \\
\text { formation, binds profilin } \\
\text { (Cdc3p) }\end{array}$ \\
\hline $\operatorname{cdc} 15$ & cdc15box/SH 3 domain & $\begin{array}{l}\Delta: \text { lethal } \\
\text { ts: no septum, assembly of } \\
\text { medial ring impaired }\end{array}$ & $\begin{array}{l}\text { lethal, blocks septation } \\
\text { rearrangement of actin } \\
\text { patches is aberrant }\end{array}$ & $\begin{array}{l}\text { localizes to medial ring, } \\
\text { required for localization of } \\
\text { Cdc12p to medial ring, } \\
\text { not required for Midlp } \\
\text { ring formation }\end{array}$ \\
\hline myo2 & myosin II & $\begin{array}{l}\Delta: \text { lethal, mal formed medial } \\
\text { ring and septum, defect in } \\
\text { cell separation }\end{array}$ & $\begin{array}{l}\text { lethal, blocks medial ring } \\
\text { formation }\end{array}$ & $\begin{array}{l}\text { component of medial ring; } \\
\text { not required for normal } \\
\text { interphase F-actin } \\
\text { structure }\end{array}$ \\
\hline plo1 & kinase & $\begin{array}{l}\Delta: \text { defective in actin ring } \\
\text { formation and initiation } \\
\text { of septum formation }\end{array}$ & $\begin{array}{l}\text { strong } O P \text { induces septation } \\
\text { in } G_{1} \text { and } G_{2} \text { cells }\end{array}$ & $\begin{array}{l}\text { required for formation of a } \\
\text { bipolar spindle }\end{array}$ \\
\hline rng2 & not cloned & $\begin{array}{l}\text { ts: defective in a late stage } \\
\text { of medial ring assembly }\end{array}$ & $?$ & \\
\hline \multicolumn{5}{|c|}{ Positioning of medial ring } \\
\hline $\operatorname{mid} 1$ & $\begin{array}{l}\text { nuclear, PH domain- } \\
\text { containing protein }\end{array}$ & $\begin{array}{l}\Delta: \text { nonlethal at low } \\
\text { temperatures, incorrect } \\
\text { placement of septum }\end{array}$ & $?$ & $\begin{array}{l}\text { aberrant } C d c 12 p \text { structures } \\
\text { formed, located in the } \\
\text { medial ring, dependent } \\
\text { upon Cdc3p, Cdc4p, } \\
\text { Cdc8p, and Cdc12p, also } \\
\text { referred to as dmf1 }\end{array}$ \\
\hline $\begin{array}{l}\text { pos1 } \\
\text { pos2 } \\
\text { pos3 }\end{array}$ & not cloned & $\begin{array}{l}\text { ts: incorrect placement of } \\
\text { septum }\end{array}$ & $?$ & \\
\hline
\end{tabular}


Table 1. (Continued)

\begin{tabular}{|c|c|c|c|c|}
\hline Gene & Gene product & $\begin{array}{c}\text { Loss of } \\
\text { function phenotype }\end{array}$ & $\begin{array}{l}\text { Overproduction } \\
\text { phenotype }\end{array}$ & Comments \\
\hline \multicolumn{5}{|c|}{ Cortical actin function } \\
\hline arp3 & actin-related & $\begin{array}{l}\Delta \text { : lethal, defective in } \\
\text { cortical actin function }\end{array}$ & lethal & $\begin{array}{l}\text { found in high } \\
\text { molecular-weight } \\
\text { complex with Sop2p, } \\
\text { interacts genetically with } \\
\text { profilin and actin, found } \\
\text { associated with actin } \\
\text { patches but not medial } \\
\text { ring }\end{array}$ \\
\hline sop2 & $\begin{array}{l}\text { transducin repeat } \\
\text { containing protein }\end{array}$ & $\begin{array}{l}\Delta \text { : lethal, defective for } \\
\text { el ongation and septation, } \\
\text { defective in cortical actin } \\
\text { function }\end{array}$ & $?$ & $\begin{array}{l}\text { interacts genetically with } \\
\text { profilin; forms cables and } \\
\text { punctate structures, found in } \\
\text { a high molecular weight } \\
\text { complex with Arp3p }\end{array}$ \\
\hline
\end{tabular}

\begin{tabular}{|c|c|c|c|c|}
\hline \multicolumn{5}{|c|}{ Required for initiating synthesis of the division septum } \\
\hline $\operatorname{cdc} 7$ & protein kinase & $\begin{array}{l}\Delta: \text { lethal, medial ring forms, } \\
\text { but no septum is made }\end{array}$ & $\begin{array}{l}\text { multiple septa without } \\
\text { cleavage }\end{array}$ & $\begin{array}{l}\text { not required for Midlp ring } \\
\text { formation }\end{array}$ \\
\hline cdc1l & not cloned & $\begin{array}{l}\text { ts: multinucleate, no } \\
\text { septum but medial ring is } \\
\text { formed }\end{array}$ & $?$ & $\begin{array}{l}\text { ts mutant suppressed by } \\
\text { increased expression of } \\
\text { Cdc7p; not required for } \\
\text { Midlp ring formation }\end{array}$ \\
\hline cdc14 & novel protein & $\begin{array}{l}\Delta \text { : lethal, multinucleate } \\
\text { cells, no septum, medial } \\
\text { ring formed }\end{array}$ & G2 delay & \\
\hline spgl & ras-superfamily GTPase & $\begin{array}{l}\Delta: \text { lethal, medial ring forms, } \\
\text { but no septum is made }\end{array}$ & $\begin{array}{l}\text { multiple septa without } \\
\text { cl eavage from } \mathrm{G}_{1} \text {, S-phase } \\
\text { or } \mathrm{G}_{2} \text {-arrested cells. }\end{array}$ & \\
\hline \multicolumn{5}{|c|}{ Required to turn off synthesis of the division septum } \\
\hline byr4 & novel protein & $\begin{array}{c}\Delta: \text { lethal, multiple septa } \\
\text { without cell cleavage, } \\
\text { nuclear abnormalities }\end{array}$ & blocks septation & $\begin{array}{l}\text { protein post-translationally } \\
\text { modified, modification } \\
\text { absent in cdc15 and cdc16 } \\
\text { mutants }\end{array}$ \\
\hline cdc16 & novel protein & $\begin{array}{l}\Delta: \text { lethal, loss of function } \\
\text { deregulates septation }\end{array}$ & $?$ & $\begin{array}{l}\text { homology to S. cerevisiae Bub2p } \\
\text { and GAP proteins, required } \\
\text { for proper mitotic arrest }\end{array}$ \\
\hline \multicolumn{5}{|c|}{ Potential regulators of septation } \\
\hline dmal & RING finger protein & $\begin{array}{l}\Delta: \text { nonlethal, but increased } \\
\text { rate of chromosome loss }\end{array}$ & blocks septation & \\
\hline nuc2 & APC component & $\begin{array}{l}\Delta: \text { lethal, metaphase arrest } \\
\text { ts: cuts at semi permissive } \\
\text { temperature }\end{array}$ & blocks septation & $\begin{array}{l}\text { synthetically lethal with } \\
\text { cut9 } \\
\text { ability to exit cycle in } \mathrm{G}_{1} \text { in } \\
\text { response to starvation is } \\
\text { compromised }\end{array}$ \\
\hline
\end{tabular}

eral organization of actin (Marks et al. 1987; Balasubramanian et al. 1992, 1994; Chang et al. 1996). Despite these abnormalities in actin patch distribution, cdc3 and cdc8 null mutants grow in a polarized fashion and die because they fail to assemble a medial ring and undergo cytokinesis, suggesting that this is the step most sensitive to their absence.
The interphase actin distribution remains normal at the restrictive temperature in cdc4, cdc12, and cdc15 heat-sensitive mutants and in the myo2 null mutant. However, during mitosis, cdc12 and cdc15 mutants show delocalized actin patches, and conditional cdc4 mutants form cables and asters emanating from one point on the cell cortex, though the cdc4 null mutant 
Table 1. (Continued)

\begin{tabular}{|c|c|c|c|c|}
\hline Gene & Gene product & $\begin{array}{l}\text { Loss of } \\
\text { function phenotype }\end{array}$ & $\begin{array}{l}\text { Overproduction } \\
\text { phenotype }\end{array}$ & Comments \\
\hline \multicolumn{5}{|c|}{ Required for cell separation } \\
\hline ppb1 & $\begin{array}{l}\text { type } 2 b \text {, cal cineurin-like } \\
\text { phosphatase }\end{array}$ & $\Delta:$ cytokinesis defect & $?$ & \\
\hline sep1 & $\begin{array}{l}\text { forkhead transcription } \\
\text { factor }\end{array}$ & $\begin{array}{l}\text { branched, multicompartmented } \\
\text { cells. }\end{array}$ & $?$ & \\
\hline sep2 & uncloned & $\begin{array}{l}\text { cell separation defect, } \\
\text { multicompartmented cells }\end{array}$ & $?$ & $\begin{array}{l}\text { al so forms double, or } \\
\text { complex septa }\end{array}$ \\
\hline spl 1 & $?$ & $\begin{array}{l}\text { branched multicompartmented } \\
\text { cells }\end{array}$ & $?$ & \\
\hline spn1 & septin & $\begin{array}{l}\Delta \text { : not lethal, cleavage } \\
\text { defect }\end{array}$ & $?$ & $\begin{array}{l}\text { found at medial ring late in } \\
\text { mitosis, and at new ends of } \\
\text { cells after separation }\end{array}$ \\
\hline
\end{tabular}

does not do this (Marks et al. 1987; Fankhauser et al. 1995; McCollum et al. 1995; Chang et al. 1996, 1997). The proteins Cdc4p, Cdc12p, Cdc15p, and Myo2p show no discrete local ization during the majority of interphase and are seen in the medial ring at the beginning of mitosis. These data are consistent with the notion that these proteins play a more specific role in the assembly and/or function of the medial ring, rather than in other actin-requiring processes. In addition to these components, at least one of the proteins required for positioning the medial ring (Midlp; see below) is also found in the medial ring.

It is clear that at the onset of septation, the medial ring constricts (Marks and Hyams 1985; Jochová et al. 1991; Fankhauser et al. 1995; McCollum et al . 1995; Chang et al. 1997; Kitayama et al. 1997). By analogy with higher eukaryotes, the medial ring has often been referred to as a contractile ring. Recently, a type II myosin heavy chain (Myo2p) has been localized to the medial ring during mitosis. The myo2 null mutant forms an aberrant medial ring, often going on to form incomplete or uncl eaved septa (Kitayama et al. 1997). Furthermore, the M yo2 $p$ ring has been observed to constrict in live cells (Kitayama et al. 1977). This result is perhaps the most persuasi ve evidence to date that an active contractile force is involved in S. pombe cell division. Targeted mutagenesis of domains of Myo2p predicted to be essential for $M$ yo2p activities should al low a test of this hypothesis in the near future. Interestingly, Myo2p differs from conventional type II myosin heavy chains in two ways. First, it contains only one IQ domain for binding to a light chain. Cdc4p, which is known to bind a large protein with ATPase activity, is related to myosin light chains (McCollum et al. 1995). However, it appears not to bind a second light chain. Given its intracellular distribution and sequence homology, Cdc4p may turn out to be the single light chain binding partner for Myo2p. Second, Myo2p contains proline residues, which are predicted to break $\alpha$-helices, in the carboxy-terminal coiled-coil re- gion. Thus, the structure of the Myo2p rod domains might be bent in several places.

Positioning the medial ring

Wild-type fission yeast almost always divides in the middle. An interesting problem is how the cell defines where the middle is when placing the medial ring at the onset of mitosis, so that the septum that forms subsequently will divide the cell equally. In a $\beta$-tubulin mutant, which has activated $C d c 2 p$ kinase but cannot form a spindle and is arrested in early mitosis, the medial ring is present and correctly placed (Chang et al. 1996). This observation indicates that formation and placement of the medial ring do not depend on either the integrity of the mitotic spindle. It is likely that the position of the premitotic nucleus defines the position of the medial ring (Chang et al. 1996; for an extended discussi on of this issue, see Chang and N urse 1996).

Several studies have identified genes (midl, posl, pos2, and pos3) that are required for correct placement of the division septum (Chang et al. 1996; Edamatsu and Toyoshima 1996; Sohrmann et al. 1996). The best characterized of these is mid1 (also called dmf1). Cells with mutations in this gene make a septum, but its position is aberrant. This can range from slightly eccentric placement, which produces daughters of unequal size, to far more extreme phenotypes, such as formation of the septum along the long axis of the cell. F-actin is always found to colocalize with the misplaced septum, suggesting that the defect lies not in forming the medial ring but in the normal mechanism for locating it at the center of the cell (Chang et al. 1996; Sohrmann et al. 1996). The midl gene is not essential, but the null allele is heat sensitive. The gene encodes a novel protein containing a putative nucl ear localization signal and a carboxy-terminal PH domain. In wild-type cells, Midlp is nuclear during interphase and relocates to form a medial ring the cell cortex coincident with the onset of mitosis. This 
Figure 2. Schematic representation of the phenotypes produced by loss-of-function mutations in genes implicated in control of septum formation. The phenotypes shown are those that would be observed in a typical experiment, two generations after a shift in the restrictive temperature. Septum material is shown in black; the nucleus in gray. A representative mutant is given for each class, and a wild-type cell is shown for comparison.
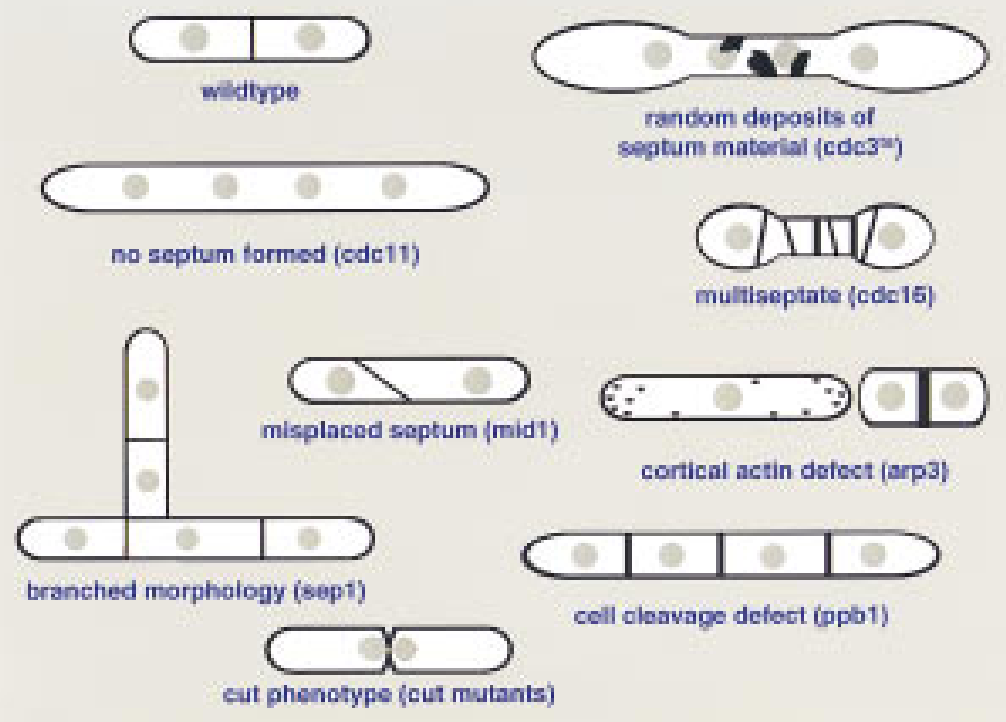

relocalization occurs before polarization of actin patches to the medial ring and is associated with increased phosphorylation of Midlp. Formation of the Midlp ring does not require an intact spindle. When the septum is completed and the cells separate, Midlp staining is once again nuclear (Sohrmann et al. 1996). One possible role of Midlp is to direct growth of the medial ring and prevent it from drifting around at the cortex. The three pos mutants (Edamatsu and Toyoshima 1996), like mid1, are defective in placing the septum at the restrictive temperature. The identity of the products they encode and their interactions with midl will be of considerable interest.

\section{Dependencies in medial ring assembly}

One important question that remains to be resolved is the role of individual medial ring components in its assembly and function. For example, are some components required only to seed the ring, whereas others act as a scaffold for its assembly and propagation around the cell cortex? To try to address this question, the effects of inactivating different components of the medial ring upon the distribution of the other components have been investigated, as reagents recognizing the various proteins have become available. To date, the localization of Cdc12p, Cdc15p, and Mid1p have been analyzed extensively.

Cdc12p does not form a ring in cdc3, cdc8, or cdc15 mutants, suggesting that the products of these genes are all required for formation or stabilization of the $C \mathrm{dc} 12 \mathrm{p}$ ring. In addition, in a cdc4 background, a single dot of Cdc12p is seen at the cell cortex, surrounded by an aster of F-actin, suggesting that Cdc4p is required for exten- sion of the ring around the cell cortex. In a midl mutant, strands of Cdc12p are seen that emanate from one point and extend in random directions (C hang et al. 1997). Mutations in cdc12 show strong negative genetic interactions with a cdc3 mutation, and Cdc12p interacts with GST -Cdc3p fusion protein directly in vitro. Cdc12p is a large multidomain protein, and it has been suggested that it may act as a nucleating scaffold for medial ring assembly (C hang et al. 1997).

Formation of the Midlp ring is dependent on Cdc3p, $\mathrm{Cdc} 4 p, \mathrm{Cdc} 8 \mathrm{p}$, and Cdc12p, al though not Cdc15p, and in synchronous cultures, the appearance of a Midlp ring precedes appearance of $C \mathrm{dc} 15 \mathrm{p}$, and pol arization of actin patches to the ring. The misplaced medial rings found in mid1 mutants are associated with Cdc15p (Sohrmann et al. 1996).

From the information above, it is clearly not possible to formulate a simple, internally consistent model describing the assembly of these components into the medial ring. These studies are obviously far from complete and need to be extended to determine the local ization of these proteins in null as well as conditional mutants, as the latter may retain some residual activity, perhaps giving misleading results. Further analysis using reagents specific for other markers will no doubt reveal additional dependency relationships in the assembly of the medial ring and will also address the relative timing with which various components appear in the ring. It will be particularly interesting to determine how far assembly can proceed in the absence of F-actin and the effects of F-actin depolymerization on it, by the use of drugs such as Latrunculin-A (Ayscough et al. 1997). It is al ready apparent, even from these early studies, that the medial ring proteins show considerable interdependency for proper localization. Models that attempt to portray medial ring 
assembly as a linear pathway may therefore be too simplistic.

\section{Regulation of medial ring assembly}

Little is known about how medial ring assembly is triggered or regulated. $M$ utants that are arrested in late $G_{2}$, such as cdc2 and cdc25, still have an interphase actin cytoskeleton, with actin patches located at the growing tips. Thus, the cytoskeletal rearrangements depend on entry into mitosis. No medial ring (as judged by visualization of F-actin) is formed in cells lacking Plolp function (Ohkura et al. 1995), suggesting that Plolp is important for triggering this rearrangement. A key element in the process may be Cdc15p: Increased expression of this protein in $\mathrm{G}_{2}$-arrested cells can provoke a rearrangement of F-actin to form either a ring or an aster at the middle of the cell, even in the absence of Cdc2p kinase activity (Fankhauser et al. 1995). Medial ring formation correlates with dephosphorylation of Cdc15p, though whether this dephosphorylation is responsible for regulating its activity remains to be determined.

Intriguingly, it has been found that $C \mathrm{dc} 12 \mathrm{p}$ and $\mathrm{M}$ yo $2 \mathrm{p}$ both form a dot between the nucleus and cell cortex in early mitotic cells (Chang et al. 1997; Kitayama et al. 1997), though these dots have only been observed when expression of the proteins is increased. The significance of these observations remains unclear. The $\mathrm{Cdc} 12 \mathrm{p}$ dot is present in late interphase cells, leading to the suggestion that this is part of the mechanism by which the site of medial ring formation is marked (Chang et al. 1997). The observation that the F-actin asters and medial rings triggered by increased expression of Cdc15p in $\mathrm{G}_{2}$-arrested cells are located at the middle of the cell (Fankhauser et al. 1995) is consistent with this view, but demonstration of a Cdc12p dot in $\mathrm{G}_{2}$-arrested cells is lacking.

Polarization of actin patches to the medial ring: the role of arp3 and sop2

As mentioned above, an obligatory step in formation of the septum is the polarization of actin patches adjacent to the medial ring. The function of these actin patches is presumably to localize properly vesicles and enzymes necessary for plasma membrane and cell wall biosynthesis during septation. The patches might al so be important for the local ization of other components necessary for medial ring function. In addition to actin, two components of the patches that are required for normal cytokinesis have been identified in S. pombe, Arp3p and Sop2p (Balasubramanian et al. 1996; McCollum et al. 1996). Arp3p and Sop2p localize to actin patches throughout the cell cycle but do not localize to the medial ring. Sop2p is al so detected in cables, which presumably al so contain actin filaments (Balasubramanian et al . 1996). Both Arp3p and Sop2p functions are essential for cell viability. Loss of either protein results in growth arrest throughout the cell cycle, an accumulation of cells with septa that are abnormally thick, di sorganization of actin patches, and cell lysis. Interestingly, an early effect of the loss of Arp3p function is a pronounced delay in actin patch relocation to the medial ring, which results in septum material being deposited at the ends of the cell rather than the medial region (McCollum et al. 1996). Mutants in Sop2p are defective in polarized cell growth after release from starvation (Balasubramanian et al. 1996). These results suggest that A rp3p and Sop2p functions are required for the normal mobility and localizati on of cortical actin patches. Arp3p and Sop2p have been structurally and functionally conserved throughout evolution and are part of a multiprotein complex (M achesky et al . 1994, 1997; Balasubramanian et al. 1996; M ullins et al. 1997; Welch et al. 1997), al though in Saccharomyces cerevisiae the purified complex lacks a sop2 homolog (Winter et al. 1997). The Arp3p-containing complex binds directly to profilin (Machesky et al . 1994), and mutations in arp3 and sop2 rescue cdc3 mutants (Bal asubramanian et al. 1996; McCollum et al. 1996). It is yet unclear what consequence these interactions have for normal cortical actin function.

\section{Regulation of the onset of septum formation}

At the restrictive temperature, mutants defective in the genes cdc7, cdc11, cdc14, and spgl do not form a division septum, but growth, DN A replication, and mitosis continue in the absence of cytokinesis (N urse et al. 1976; Mitchison and Nurse 1985; Fankhauser and Simanis 1993, 1994; Schmidt et al. 1997), resulting in the formation of multinucleate cells. The cdc7, cdc14, and spg1 genes (but not cdcl1) have been cloned and sequenced. All three genes are essential. In each case the null mutant shows the same phenotype as the heat-sensitive mutant. These mutants can al I form a medial ring during mitosis; so it is likely that the gene products act either downstream or independently from the genes that are required for formation of the medial ring. In null mutants where this has been examined (spgl and cdc7), the medial ring does not appear to contract significantly. Mutations in these genes show strong genetic interactions, suggesting that the gene products function in a single biochemical pathway (Marks et al. 1992). Because the plol-encoded protein kinase is required not only for medial ring formation but al so for initiating septum formation (Ohkura et al. 1995), activation of these genes may also require Plolp function. However, to date, there is no genetic or biochemical evidence linking PIolp with this pathway. The identity of the substrates of Plolp will be of considerable interest.

The cdc7 gene encodes a protein kinase. Overexpression of the gene deregulates septum formation and causes a cell cycle arrest with a phenotype si milar to that of a cdc $16^{\text {ts }}$ mutant (see below). This overexpression phenotype requires functional Cdc11p, Cdc14p, and Cdc15p. In addition, slightly increased expression of Cdc7p, to levels that do not perturb significantly the normal regulation of septum formation, is sufficient to rescue mutations in cdcll. These observations suggest that Cdc7p and Cdc1lp interact in the same pathway (Fankhauser and Simanis 1994). 
The spgl gene was cl oned as a multicopy suppressor of a dominant-negative mutant of the $\mathrm{Cdc7p}$ kinase and as a suppressor of cdc11 mutations (Schmidt et al. 1997). It is an essential gene, which encodes a GTPase of the ras superfamily. Increased expression of Spglp induces septum formation in $\mathrm{G}_{2^{-}}$, $\mathrm{S}$ phase-, or pre-Start $\mathrm{G}_{1}$-arrested cells. In addition to breaking the normal dependency on initiation of mitosis, spgl overexpression (like cdc7 overexpression) deregulates septum formation, resulting in formation of multiple septa that are not cleaved. This effect requires the activities of $C d c 7 p, C d c 15 p$, and Cdc14p, but not Cdc2p. Spglp and Cdc7p can be coimmunoprecipitated from cell extracts; whether this interaction is required for localization of $C \mathrm{dc} 7 \mathrm{p}$, for its kinase activity, or both will be of interest.

The predicted sequence of Cdc14p, a 28-kD protein, gives no clues to its biochemical function. Overproduction of the protein delays the onset of mitosis and cytoskeletal rearrangement (Fankhauser and Simanis 1993).

\section{Synthesis of the division septum}

The main components of the S. pombe cell wall are branched $(1 \rightarrow 3) \beta$-glucan, linear $(1 \rightarrow 3) \alpha$-glucan, and $\alpha$-galactomannan (Horisberger and Rouvet-Vauthey 1984): ( $1 \rightarrow 3$ ) $\beta$-Glucan is also a component of the division septum. Recent studies indicate that Rho-family GTPases are involved in controlling the activity of $\beta$ glucan synthase (Arellano et al. 1996) and that activated mutants make a very thick wall and very little septum material. It is not known at present how the synthetic enzymes are directed to the site of septum formation.

\section{Tuming off septum formation}

To date, two mutants have been described that cannot turn off septum formation once it has been initiated. In a cdc16 mutant, cells complete mitosis normally and form a septum between the two nuclei. However, instead of proceeding to cell cleavage, the cell synthesizes multiple, additional septa. These are not formed simultaneously but instead are laid down one at a time, producing anucleate cell compartments (M inet et al. 1979). A similar phenotype is produced by loss of byr4 function, although in this case, mitotic abnormalities are also observed (Song et al. 1996). Therefore, Byr4p and Cdc16p are implicated in limiting the cell to a singl e septum per cell cycle. Synthetic lethal interactions and suppression have been observed between cdc16 and genes required for the onset of septum formation, such as cdc7, cdc11, and cdc14, suggesting that $\mathrm{Cdc16p}$ is a component of the same pathway ( $M$ arks et al. 1992); however, this remains to be establ ished biochemically. Because loss of Cdc16p activity also compromizes the function of the checkpoint that monitors spindle integrity and/or function during mitosis, it has been suggested that $\mathrm{Cdc16p}$ may play a dual role in the cell cycle (Fankhauser et al. 1993). Cdc16p is most cl osely related to S. cerevisiae Bub2p and shares homology with GTPase-activating proteins (GAPs) (Schmidt et al. 1997). It is tempting to speculate that it will be the GAP for Spglp and that the Spglp GTPase switch is the key, rate-limiting step in the initiation of septum formation at the end of mitosis (Schmidt et al . 1997). However, this remains to be demonstrated. The sequence of Byr4p gives no clue as to its function, although the protein has a short region of homology with Cdc7p, the significance of which is presently unknown (Song et al. 1996). Byr4p is subject to post-translational modification that alters its migration on SDS-polyacrylamide gels. This modification is reduced in cdc15 and cdc16 mutants and is very extensive in a cell arrested in early mitosis (Song et al. 1996). Whether this modification plays any role in coupling the onset of septation with mitosis remains to be determined.

\section{Cell separation}

A number of mutants defective in cell separation have been identified, al though to date, little is known of the biochemical pathways involved. Mutations in sepl interfere with cell separation and result in a branched, mycelial morphology. The spl1-1 mutation results in a terminal phenotype showing characteristics of both sepl and heat-sensitive medial ring formation mutants (Sipiczki et al. 1993). Under restrictive conditions, spl 1-1 cells are mononucl eate, are elongated, have an abnormal shape, and contain one or more uncleaved or partially cleaved septa, together with irregular depositions of cell wall material. sepl has been cloned; it encodes a fork head-type putative transcription factor (Ribar et al. 1997). This raises the possibility that expression of certain genes late in the cell cycle is required for efficient cell separation. Consistent with this hypothesis, addition of cycloheximide late in mitosis prevents cell cleavage but not synthesis of the septum (Fantes 1982; Sohrmann et al. 1996).

A screen for mutants showing increased resistance to cell wall-digesting enzymes has yielded a new series of sep mutants. The one analyzed in detail, sep2, shows a linear rather than branched morphology. In addition, cells often form complex or double septa (Grallert et al. 1997).

Septins are also implicated in cell separation in fission yeast. S. pombe has at least six septin genes (Longtine et al. 1996). Spn 1p appears to function in cell division; in particular it seems to be required for a late stage of septum formation or perhaps cell wall dissolution, because a null mutant is viable, but has a del ay in cell separation or in completing the septum. The phenotype resembles that of sep1. Septins local ize to the site of the medial ring very late in mitosis, after association of actin and related proteins (cited in Longtine et al. 1996).

It is likely that phosphatases are also important in regulating the septation machinery and activating cell cleavage. Treatment of cells with okadaic acid interferes with septation and cytokinesis, producing binucleate cells with or without a septum (Kinoshita et al. 1993). Cytokinesis is also inhibited by the drug cyclosporin A or mutation of its main target, the cal cineurin-like type 
2B phosphatase encoded by ppb1 (Yoshida et al. 1994); the affected cells can form septa, but cell separation is impeded. Cytokinesis and morphology defects are also produced by mutation of the protein phosphatase $2 \mathrm{~A}$ regulatory subunit gene, pab1 (Kinoshita et al. 1996). Genetic interactions between $\mathrm{ppb} 1$ and other phosphatase genes have al so been observed. Double mutants of ppb1 with either dis2 or ppa2 show a cytokinesis defect, which is even more extreme in the ppbl stsl double mutant. The protein kinase $C$ pathway has also been shown to affect cell division. Overexpression of pkc2 is lethal, producing branched, multiseptate cells (Toda et al. 1993), whereas lack of Pkc2p affects cell shape and polarity and renders protoplasts unable to resynthesize cell wall or reorganize F-actin for polar growth (Kobori et al. 1994).

Induction of septum formation by increased expression of Spglp or Cdc7p or inactivation of Cdc16p or Byr4p results in multiple septa being formed without cell cleavage. This could be because the septa produced under these conditions are in some way defective, because the presence of anucleate compartments prevents cleavage (i.e., a septum needs a nucleus on either side to be cleaved), or because the cleavage signal is ignored or not given while the septum-synthesizing machinery is active. In certain cases, such as the long cells produced by cdc 25 arrest and release or by combining sep2 with mutations that increase cell length, doubl e septa are produced, generating an anucl eate compartment that separates the two nucleated ones. In these cases, one and sometimes both of the septa are cleaved (Grallert et al. 1997). It is thus unlikely that there is an obligatory requirement for a nucleus to be situated on each side of a septum for cleavage to occur. Though it seems likely that there will be a signal to initiate septum dissolution, its biochemical nature remains unknown.

\section{Coordinating mitosis and cytokinesis}

Analysis of the phenotypes of different cell cycle mutants has led to the conclusion that septum formation is dependent on the initiation, although not on the completion, of mitosis. Thus, no septum formation is observed in cells blocked in late $G_{2}$ by a defect in cdc2 function (N urse et al. 1976; Minet et al. 1979). As mentioned above, mutants that arrest in the early stages of mitosis because of defects in $\beta$-tubul in form a medial ring but do not make a division septum. The cell cycle arrest in this case is imposed by activation of the spindle assembly checkpoint (for review, see Wells 1996). If progression through mitosis is delayed, the cell must al so restrain septum formation to avoid cutting the undivided nucleus. Loss of Cdc16p function compromizes the checkpoint-induced arrest in mitotically arrested cells (Fankhauser et al. 1993). Dmalp, which was isol ated as a multi copy suppressor of cdc16-116, may be an effector of the checkpoint signal transduction pathway (Murone and Simanis 1996). dmal is nonessential, but if Dmalp function is lacking, septation is not blocked in cells arrested in early mitosis. Increased expression of Dmalp initially blocks septum formation, whereas $\mathrm{S}$ phase and mitosis continue, producing elongated, multinucleate cells; medial rings are formed; so it is apparently the onset of septum formation that is inhibited. The targets and regulation of Dmalp will be of interest.

Certain mutants that arrest at late stages in mitosis are unable to restrain cytokinesis and form a division septum, resulting in the cleavage of the undivided nucleus by the septum to produce the so-called cut (cell untimely torn) phenotype. To date, $>20$ cut genes have been described (Hirano et al. 1986; Samejima et al. 1993; Saka et al. 1994), and mutations in the top2 gene also produce this phenotype (Uemura and Yanagida 1984). It is clear that many, although not all, of the proteins encoded by the cut genes are required either for anaphase onset or postanaphase events, or that lack of the protein interferes with proper chromosome segregation. The observation that cells arrested early in mitosis do not cut, taken together with the existence of cut mutants, suggests that there is a "point of no return" during mitosis when a cell commits to septation and thereafter cannot delay the process very much if later events do not occur properly. However, it is also clear that some delay must be possible, because in the long cells produced by increased expression of weel or by block and release of a cdc25 mutant, anaphase is extended, and septation is delayed correspondingly until after spindle breakdown (Hagan et al. 1990).

The finding that some cut genes (nuc2, cut9, and cut4) encode components of the 20S APC/cyclosome $\mathrm{Ya}$ mashita et al. 1996; Yamada et al. 1997) suggests that this complex is not involved directly in triggering the onset of septum formation. However, an unexplained result is that strong ectopic expression of nuc 2 inhibits septum formation, producing long, multinucleate cells similar to those produced by mutations in cdc7 or cdcll (Kumada et al. 1995). Because mitosis continues normally in these cells, the 20S A PC/cyclosome is presumably functioning properly. It is not known at this time which stage of septum formation is blocked by nuc2 overproduction, because it has not been determined whether these cells form medial rings. It is possible that the excess $\mathrm{N}$ uc $2 \mathrm{p}$ titrates away some component essential for septum formation. Although the data cited above argue that the involvement of the 20S APC/cyclosome may not be direct, septum formation may be initiated by the same cues that activate the 20S APC/cyclosome to bring about anaphase onset. The role played by proteolysis in controlling the onset of septum formation therefore remains to be elucidated.

\section{The role of Cdc $2 p$}

cdc2 mutants arrest in $\mathrm{G}_{2}$ and do not initiate mitosis or any of the cytoskeletal rearrangements associated with it. Thus, these rearrangements are normal ly coordinated with entry into mitosis. However, increased expression of some genes (cdc15: Fankhauser et al. 1995; plo1: Ohkura et al. 1995; spg1: Schmidt et al. 1997) can bypass this requirement and induce septation or at least some of 
the cytoskeletal rearrangements, even though $C d c 2 p$ is inactivated by mutation. Thus, the activation of these septum-promoting proteins may normally be coupled to the activation of $\mathrm{Cdc} 2 \mathrm{p}$ or to its inactivation during mitosis. How this is achieved is unclear presently. However, in view of the central role that it appears to play both in establishing a bipolar spindle and in medial ring and septum formation, it is probable that Plolp kinase will also be of importance.

Inactivation of $\mathrm{Cdc} 2 \mathrm{p}$ kinase may be a critical step in signaling the onset of septum formation. If cells are arrested in mitosis by increased expression of $\mathrm{S}$. pombe Mad2p, and Cdc2p or Cdc13p (the B-type cyclin with which it associates) is inactivated, cells form a division septum (He et al. 1997). A similar result was obtained in S. cerevisiae, where inactivation of Cdc28p in a mitotically arrested cell is sufficient to trigger cell cleavage (Ghiara et al. 1991).

In higher eukaryotes, studies of myosin II regulatory light chain phosphorylation also indicate a role for Cdc2p inactivation in triggering cytokinesis. Myosin II regulatory light chain activity appears to be both negatively and positively regulated by changes in phosphorylation. During mitosis, it is inhibited through phosphorylation by Cdc2p/Cyclin B (Satterwhite et al. 1992). When $\mathrm{Cdc} 2 \mathrm{p} / \mathrm{Cyclin} \mathrm{B}$ is inactivated in the normal cell cycle, coincident with the metaphase-anaphase transition, these phosphorylations no longer occur. At this time, phosphorylation of another site by myosin light chain kinase is increased markedly. The changes at these phosphorylation sites are thought to contribute to signaling the initiation of cytokinesis (Yamakita et al. 1994). Thus, inactivation of Cdc2p kinase at the end of mitosis may be a universal feature in signal ing the onset of cytokinesis.

\section{Checkpoints}

Are there checkpoints operating during medial ring assembly, septum formation, and cytokinesis? The existence of a checkpoint that delays mitosis if bud formation is compromized has been demonstrated in S. cerevisiae (Lew and Reed 1995; Sia et al. 1996). The observation that cleavage is delayed in midl mutant cel Is that have drastical ly mispl aced their septum or created an anucleate compartment suggests that some form of sensor mechanism must operate during septation (Chang et al. 1996; Sohrmann et al. 1996). In addition, the septum-forming machinery responds to activation of the mitotic checkpoint, if spindle function is compromized (see above). However, mutants such as cdcll, which assemble a medial ring but are unable to trigger the onset of septum formation, rearrange actin to thetips of the cell at the end of mitosis and resume growth without cytokinesis, repeating this at each nuclear division (M itchison and N urse 1985; M arks et al . 1987). This may mean that there is no septum formation checkpoint, that it is only activated if septation is actually triggered, or that the proteins required to trigger it are themselves part of the sensor/transduction mechanism. Although it is presently not clear which of these possibilities (if any) is correct, it may be that in the wild this is not as serious a problem as it would at first appear to be. Because "wild" S. pombe are homothallic and therefore switch mating type, a cell skipping septation may end up with two nuclei that express different mating-type cassettes in the same cytoplasm. Under these conditions, if the cell is starved (likely in the wild), it will undergo karyogamy and meiosis, solving the problem of not having divided. The nature of the checkpoint, if one exists, will be of considerable interest.

\section{Microtubules}

To date, the localization of F-actin correlates best with the sites of growth and division. However, it is also clear that microtubules cannot be ignored in this context. For example, there is a continuous requirement for intact microtubules to direct Tealp to the tips of the cells, where it is essential to maintain proper growth polarity (Mata and N urse 1997). In addition, the postanaphase microtubule array (PAA) that appears at the end of mitosis is seeded from microtubule-organizing centers at the cell equator (Hagan and Hyams 1988). Interestingly, in cells that misplace the division septum, the PAA is al so misplaced, suggesting that the site of division determines where the new microtubule array will be seeded from at the end of mitosis (Chang et al. 1996). Furthermore, it has been reported that in addition to a medial F-actin-containing ring at the cell cortex, there is al so a ring of microtubules at the cell equator during mitosis (Pichová et al. 1995). Although, to date, attention has focused mostly on the role of actin, it is possible that future models will also have to incorporate an active role for microtubules in formation of the division septum.

\section{Evolutionary conservation of the fission yeast division machinery}

Many of the components implicated in assembly of the medial ring or in control of actin polymerization or distribution have been functionally conserved through eukaryotic evolution. In many cases, for example, the septins, Cdc12p/Diaphanous-like proteins, profilin, tropomyosin, type II myosin, and myosin light chain (for review, see Satterwhite and Poll ard 1992; Longtine et al . 1996; Frazier and Field 1997), these components are al so implicated in cytokinesis. Anillin, an actin-binding protein from Drosophila melanogaster (Field and Alberts 1995), has many of the structural motifs of Midlp and cycles from the nucleus to the cell cortex at the time of division; it is tempting to speculatethat it plays a similar role to Midlp in defining the site where the contractile ring will form. The study of yeast mutants has al so identified molecules that are potential regulators of cytokinesis. Some of these proteins, such as Plolp, Cdc7p, Spglp, and Cdc16p, have functional counterparts in S. cerevisiae, though their rol e in this organism seems to be concerned mainly with regulating the end of mitosis, perhaps reflecting the different mode of growth and di- 
vision of the two organisms (Kitada et al. 1993; Surana et al. 1993; Shirayama et al . 1994a,b, 1996). It will be interesting to determine whether these proteins have homologs in higher eukaryotes.

\section{Future prospects}

It is clear that mutant screens are far from saturated, and one would expect many new regulators both of medial ring formation and septum formation to emerge from new mutants hunts. In addition, the increasing amount of information from genome-sequencing projects and purification of actin-regulating complexes from organisms more amenable to bi ochemistry than yeast cells will allow cloning of genes for proteins that regulate division but for which yeast mutants are not yet available. Thus, the extent to which the control mechanisms identified in yeasts are appl icable to higher eukaryotes should soon become evident. A few of the many outstanding questions in the $\mathrm{S}$. pombe system that will surely be addressed in the future are: (1) How is the assembly of the medial ring influenced by genes control ling cell polarity? (2) What is the role of the nucleus in determining the site of division? (3) What role do microtubules play in controlling cell division, and how do the actin and microtubule cytoskel etal el ements interact? (4) What signals the onset of medial ring contraction/septum biosynthesis? and (5) How does the cell know that the septum has been completed, and what triggers dissol ution of the septum?

\section{Acknowledgments}

We are grateful to $\mathrm{D}$. McCollum for pointing out the similarity between Midlp and Anillin to us. We also thank one of the referees for many constructive suggestions and fastidious editing of the manuscript. K.L.G. is an assistant investigator of the Howard Hughes Medical Institute. V.S. receives support from the Swiss Cancer League, Swiss N ational Science Foundation, and the Swiss Institute for Experimental Cancer Research.

\section{References}

Arellano, M., A. Durán, and P. Pérez. 1996. Rhol GTPase activates the 1-3 $\beta-D$ glucan synthase and is involved in $S$. pombe morphogenesis. EMBO J. 15: 4584-4591.

Ayscough, K.R., J. Stryker, N. Pokala, M. Sanders, P. Crews, and D.G. Drubin. 1997. High rates of actin filament turnover in budding yeast and roles for actin in establishment and maintenance of cell polarity revealed using the actin inhibitor Latrunculin-A. J. Cell Biol. 137: 399-416.

Bal asubramanian, M.K., D.M. Helfman, and S.M. Hemmingsen. 1992. A new tropomyosin essential for cytokinesis in the fission yeast S. pombe. Nature 360: 84-87.

Bal asubramanian, M.K., B.R. Hirani, J.D. Burke, and K.L. Gould. 1994. The Schizosaccharomyces pombe cdc3 gene encodes a profilin essential for cytokinesis. J. Cell Biol. 125: 1289-1301.

Balasubramanian, M.K., A. Feoktistova, D. McCollum, and K.L. Gould. 1996. Fission yeast Sop2p: A novel and evolutionarily conserved protein that interacts with Arp3p and modulates profilin function. EMBO J. 15: 6426-6437.
Broek, D., R. Bartlett, K. Crawford, and P. N urse. 1991. Involvement of p34 ${ }^{\text {cdc2 }}$ in establishing the dependency of $S$ phase on mitosis. Nature 349: 388-393.

Chang, F. and P. N urse. 1996. How fission yeast fission in the middle. Cell 84: 191-194.

Chang, F., A. Woollard, and P. N urse. 1996. Isolation and characterization of fission yeast mutants defective in the assembly and placement of the contractile actin ring. J. Cell Sci. 109: 131-142.

Chang, F., D. Drubin, and P. N urse. 1997. Cdc12p, a protein required for cytokinesis in fission yeast, is a component of the cell division ring and interacts with profilin. J. Cell Biol. 137: 169-182.

Edamatsu, M. and Y.Y. Toyoshima. 1996. Isolation and characterization of pos mutants defective in correct positioning of septum in Schizosaccharomyces pombe. Zool. Sci. 13: 235239.

Fankhauser, C. and V. Simanis. 1993. The Schizosaccharomyces pombe cdc14 gene is required for septum formation and can also inhibit nuclear division. Mol. Biol. Cell 4: 531-539.

_-_. 1994. The cdc7 protein kinase is a dosage-dependent regulator of septum formation in fission yeast. EMBO J. 13: 3011-3019.

Fankhauser, C., J. Marks, A. Reymond, and V. Simanis. 1993. TheS. pombe cdc16 gene is required both for maintenance of p34 ${ }^{\text {cdc2 }}$ kinase activity and regulation of septum formation: A link between mitosis and cytokinesis? EMBO J. 12: 26972704.

Fankhauser, C., A. Reymond, L. Cerutti, S. Utzig, K. Hofmann, and V. Simanis. 1995. The S. pombe cdc15 gene is a key element in the reorganization of F-actin at mitosis. Cell 82: 435-444.

Fantes, P.A. 1982. Dependency relations between events in mitosis in Schizosaccharomyces pombe. J. Cell Sci. 55: 383402.

Field, C.M. and B.M. Alberts. 1995. Anillin, a contractile ring protein that cycles from the nucleus to the cell cortex. J. Cell Biol. 131: 165-178.

Frazier, J.A. and C.M. Field. 1997. The actin cytoskel eton-Are FH proteins local organizers? Curr. Biol. 7: 414-417.

Ghiara, J.B., H.E. Richardson, K. Sugimoto, M. Henze, D.J. Lew, C. Wittenberg, and S.I. Reed. 1991. A cyclin B homolog in S. cerevisiae: Chronic activation of the $\mathrm{Cdc} 28$ protein kinase by cyclin prevents exit from mitosis. Cell 65: 163-174.

Grallert, A., I. Miklos, and M. Sipiczki. 1997. Division-site selection, cell separation, and formation of anucleate minicells in Schizosaccharomyces pombe mutants resistant to cellwall Iytic enzymes. Protoplasma 198: 218-229.

Hagan, I.M. and J.S. Hyams. 1988. The use of cell division cycle mutants to investigate the control of microtubule distribution in the fission yeast Schizosaccharomyces pombe. J. Cell Sci. 89: 343-357.

Hagan, I.M., P.N. Riddle, and J.S. Hyams. 1990. Intramitotic controls in the fission yeast Schizosaccharomyces pombe: The effect of cell size on spindle length and the timing of mitotic events. J. Cell Biol. 110: 1617-1621.

He, X., T.E. Patterson, and S. Sazer. 1997. The S. pombe spindle checkpoint protein mad2p blocks anaphase and genetically interacts with the APC. Proc. Natl. Acad. Sci. 94: 79657970.

Hirano, T., S. Funahashi, T. U emura, and M. Yanagida. 1986. Isolation and characterization of Schizosaccharomyces pombe cut mutants that block nuclear division but not cytokinesis. EMBO J. 5: 2973-2979.

Horisberger, M. and M. Rouvet-Vauthey. 1984. Localization of glycosylated kappa-casein on thin sections of casein micelles 
by lectin-labelled gold markers. Histochemistry $\mathbf{8 0 :} 523-$ 526.

Ishiguro, J. and W. Kobayashi. 1996. An actin point-mutation neighbouring the 'hydrophobic plug' causes defects in the maintenance of cell polarity and septum organization in the fission yeast Schizosaccharomyces pombe. FEBS Letts. 392: 237-241.

Jochová, J., I. Rupeš, and E. Streiblová. 1991. F-actin contractile rings in protoplasts of the yeast Schizosaccharomyces. Cell Biol. Int. Rep. 15: 607-610.

Johnson, B.F., B.Y. Yoo, and G.B. Calleja. 1973. Cell division in yeasts: Movement of organelles associated with cell plate growth of Schizosaccharomyces pombe. J. Bacteriol. 115: 358-366.

Kanbe, T., I. Kobayashi, and K. Tanaka. 1989. Dynamics of cytoplasmic organelles in the cell cycle of the fission yeast $S$. pombe: Three-dimensional reconstruction from serial sections. J. Cell Sci. 94: 647-656.

Kinoshita, K., T. N emoto, K. N abeshima, H. Kondoh, H. Niwa, and $M$. Yanagida. 1996. The regulatory subunits of fission yeast protein phosphatase 2A (PP2A) affect cell morphogenesis, cell wall synthesis and cytokinesis. Genes to Cells 1: $29-45$.

Kinoshita, N., H. Yamano, H. Niwa, T. Yoshida, and M. Yanagida. 1993. Negative regulation of mitosis by fission yeast protein phosphatase ppa2. Genes \& Dev. 7: 1059-1071.

Kitada, K., A.L. Johnson, L.H. Johnston, and A. Sugino. 1993. A multicopy suppressor gene of the Saccharomyces cerevisiae $\mathrm{G} 1$ cell cycle mutant gene dbf4 encodes a protein kinase and is identified as CDC5. Mol. Cell. Biol. 13: 4445-4457.

Kitayama, C., A. Sugimoto, and M. Yamamoto. 1997. Type II myosin heavy chain encoded by the myo2 gene composes the contractile ring during cytokinesis in Schizosaccharomyces pombe. J. Cell Biol. 137: 1309-1319.

Kobori, H., T. Toda, H. Yaguchi, M. Toya, M. Yanagida, and M. Osumi. 1994. Fission yeast protein kinase $C$ homologs are required for protoplast regeneration: $A$ functional link be tween cell wall formation and cell shape control. J. Cell Sci. 107: 1131-1136.

Kumada, K., S. Su, M. Yanagida, and T. Toda. 1995. Fission yeast TPR-family protein nuc2 is required for $\mathrm{G} 1$-arrest upon nitrogen starvation and is an inhibitor of septum formation. J. Cell Sci. 108: 895-905.

Lew, D.J. and S.I. Reed. 1995. A cell cycle checkpoint monitors cell morphogenesis in budding yeast. J. Cell Biol. 129: 739749.

Longtine, M.S., D.J. DeM arini, M.L. Valencik, O.S. Al-Awar, H. Fares, C. De Virgilio, and J.R. Pringle. 1996. The septins: Roles in cytokinesis and other processes. Curr. Opin. Cell Biol. 8: 106-119.

Machesky, L.M., S.J. Atkinson, C. Ampe, J. Vandekerckhove, and T.D. Pollard. 1994. Purification of a cortical complex containing two unconventional actins from Acanthamoeba by affinity chromatography on profilin-agarose. J. Cell Biol. 127: 107-115.

Machesky, L.M., E. Reeves, F. Wientjes, F. Mattheyse, A. Grogan, N .F. Totty, A.L. Burlingame, J.J. Hsuan, and A.W. Segal. 1997. The mammalian Arp2/3 complex localizes to regions of lamellipodial protrusion and is composed of evolutionarily conserved proteins. Biochem. J. (in press).

Marks, J. and J.S. Hyams. 1985. Localization of F-actin through the cell division cycle of Schizosaccharomyces pombe. Eur. J. Cell Biol. 39: 27-32.

Marks, J., I.M. Hagan, and J.S. Hyams. 1986. Growth polarity and cytokinesis in fission yeast: The role of the cytoskele ton. J. Cell Sci. (Suppl.) 5: 229-241.
- - - 1987. Spatial association of F-actin with growth polarity and septation in the fission yeast Schizosaccharomyces pombe. Spec. Publ. Soc. Gen. Microbiol. 23: 119-135.

M arks, J., C. Fankhauser, and V. Simanis. 1992. Genetic interactions in the control of septation in Schizosaccharomyces pombe. J. Cell Sci. 101: 801-808.

Mata, J. and P. Nurse. 1997. Teal and the microtubular cytoskeleton are important for generating global spatial order within the fission yeast cell. Cell 89: 939-949.

M cCollum, D., M.K. Bal asubramanian, L.E. Pelcher, S.M. Hemmingsen, and K.L. Gould. 1995. Schizosaccharomyces pombe $c d c 4^{+}$gene encodes a novel EF-hand protein essential for cytokinesis. J. Cell Biol. 130: 651-660.

McCollum, D., A. Feoktistova, M. M orphew, M. Balasubramanian, and K.L. Gould. 1996. The Schizosaccharomyces pombe actin-related protein, Arp3, is a component of the cortical actin cytoskeleton and interacts with profilin. EMBO J. 15: 6438-6446.

Minet, M., P. Nurse, P. Thuriaux, and J.M. Mitchison. 1979. Uncontrolled septation in a cell division cycle mutant of the fission yeast Schizosaccharomyces pombe. J. Bacteriol. 137: 440-446.

Mitchison, J.M . and P. N urse. 1985. Growth in cell length in the fission yeast Schizosaccharomyces pombe. J. Cell Sci. 75: 357-376.

Mulholland, J., D. Preuss, A. Moon, A. Wong, D. Drubin, and D. Botstein. 1994. Ultrastructure of the yeast actin cytoskeleton and its association with the plasma membrane. J. Cell Biol. 125: 381-391.

Mullins, R.D., W.F. Stafford, and T.D. Pollard. 1997. Structure, subunit topology, and actin-binding activity of the Arp2/3 complex from Acanthamoeba. J. Cell Biol. 136: 331-343.

Murone, M. and V. Simanis. 1996. The fission yeast dmal gene is a component of the spindle assembly checkpoint, required to prevent septum formation and premature exit from mitosis if spindle function is compromized. EMBO J. 15: 66056616.

N urse, P., P. Thuriaux, and K. N asmyth. 1976. Genetic control of the cell division cycle in the fission yeast Schizosaccharomyces pombe. Mol. \& Gen. Genet. 146: 167-178.

Ohkura, H., I.M. Hagan, and D.M. Glover. 1995. The conserved S. pombe kinase plo1, required to form a bi polar spindle, the actin ring, and septum, can drive septum formation in $\mathrm{G}_{1}$ and $G_{2}$ cells. Genes \& Dev. 9: 1059-1073.

Pichová, A., S.D. Kohlwein, and M. Yamamoto. 1995. N ew arrays of cytoplasmic microtubules in the fission yeast Schizosaccharomyces pombe. Protoplasma 188: 252-257.

Ribar, B., A. Bánrévi, and M. Sipiczki. 1997. sep1+ encodes a transcription-factor homolog of the HN F-3/fork-head DNAbinding-domain family in Schizosaccharomyces pombe. Gene (in press).

Robinow, C.F. and J.S. Hyams. 1989. General cytology of fission yeasts. In The molecular biology of the fission yeast (ed. A. Nasim, P.G. Young, and B.F. Johnson), pp. 273-330. Academic Press, N ew York, NY.

Saka, Y., T. Sutani, Y. Yamashita, S. Saitoh, M. Takeuchi, Y. Nakaseko, and M. Yanagida. 1994. Fission yeast cut3 and cut14, members of a ubiquitous protein family, are required for chromosome condensation and segregation in mitosis. EMBO J. 13: 4938-4952.

Samejima, I., T. M atsumoto, Y. N akaseko, D. Beach, and M. Yanagida. 1993. Identification of seven new cut genes involved in Schizosaccharomyces pombe mitosis. J. Cell Sci. 105: 135-143.

Satterwhite, L.L. and T.D. Pollard. 1992. Cytokinesis. Curr. Opin. Cell Biol. 4: 43-52. 
Satterwhite, L.L., M.J. Lohka, K.L. Wilson, T.Y. Scherson, L.J. Cisek, J.L. Corden, and T.D. Pollard. 1992. Phosphorylation of myosin-II regulatory light chain by cyclin-p34cdc2: A mechanism for the timing of cytokinesis. J. Cell Biol. 118: $595-605$.

Schmidt, S., M. Sohrmann, K. Hofmann, A. Woollard, and V. Simanis. 1997. The Spglp GTPase is an essential, dosagedependent inducer of septum formation in Schizosaccharomyces pombe. Genes \& Dev. 11: 1519-1534.

Shirayama, M., Y. M atsui, and A. Toh-e. 1994a. Theyeast TEM 1 gene, which encodes a GTP-binding protein, is involved in termination of $\mathrm{M}$ phase. Mol. Cell. Biol. 14: 7476-7482.

Shirayama, M., Y. Matsui, K. Tanaka, and A. Toh-e. 1994b. Isolation of a CDC25 family gene, MSI2/LTE1, as a multicopy suppressor of iral. Yeast 10: 451-461.

Shirayama, M., Y. Matsui, and A. Toh-e. 1996. Dominant mutant al leles of yeast protein kinase gene CDC 15 suppress the Itel defect in termination of $M$ phase and genetically interact with CDC14. Mol. \& Gen. Genet. 251: 176-185.

Sia, R.A., H.A. Herald, and D.J. Lew. 1996. Cdc28 tyrosine phosphorylation and the morphogenesis checkpoint in budding yeast. Mol. Biol. Cell 7: 1657-1666.

Si piczki, M., B. Grallert, and I. Miklos. 1993. Mycelial and syncytial growth in Schizosaccharomyces pombe induced by novel septation mutations. J. Cell Sci. 104: 485-493.

Sohn, R.H. and P.J. Goldschmidt-Clermont. 1994. Profilin: At the crossroads of signal transduction and the actin cytoskeleton. BioEssays 16: 465-472.

Sohrmann, M., C. Fankhauser, C. Brodbeck, and V. Simanis. 1996. The dmfl/midl gene is essential for correct positioning of the division septum in fission yeast. Genes $\&$ Dev. 10: 2707-2719.

Song, K., K.E. M ach, C.-Y. Chen, T. Reynolds, and C.F. Albright. 1996. A novel suppressor of rasl in fission yeast, byr4, is a dosage-dependent inhibitor of cytokinesis. J. Cell Biol. 133: 1307-1319.

Surana, U., A. Amon, C. Dowzer, J. McGrew, B. Byers, and K. N asmyth. 1993. Destruction of the CDC28/CLB mitotic kinase is not required for the metaphase to anaphase transition in budding yeast. EMBO J. 12: 1969-1978.

Theriot, J.A. and T.J. Mitchison. 1993. The three faces of profilin. Cell 75: 835-838.

Toda, T., M. Shimanuki, and M. Yanagida. 1993. Two novel protein kinase $\mathrm{C}$-related genes of fission yeast are essential for cell viability and implicated in cell shape control. EMBO J. 12: 1987-1995.

Uemura, T. and M. Yanagida. 1984. Isolation of type I and II DN A topoisomerase mutants from fission yeast: Single and double mutants show different phenotypes in cell growth and chromatin organisation. EMBO J. 3: 1737-1744.

Welch, M.D., A. Iwamatsu, and T.J. Mitchison. 1997. Actin polymerization is induced by Arp2/3 protein complex at the surface of Listeria moncytogenes. Nature 385: 265-269.

Wells, W.A.E. 1996. The spindle-assembly checkpoint: Aiming for a perfect mitosis, every time. Trends Cell Biol. 6: 228234.

Winter, D., A.V. Podtelejnikov, M. Mann, and R. Li. 1997. The complex containing actin-related proteins Arp2 and Arp3 is required for the motility and integrity of yeast actin patches. Curr. Biol. 7: 519-529.

Yamada, H., K. Kumada, and M. Yanagida. 1997. Distinct subunit functions and cell cycle regulated phosphorylation of 20S APC / cyclosome required for anaphase in fission yeast. J. Cell Sci. 110: 1793-1804.

Yamakita, Y., S. Yamashiro, and F. Matsumura. 1994. In vivo phosphorylation of regulatory light chain of myosin II during mitosis of cultured cells. J. Cell Biol. 124: 129-137.

Yamashita, Y.M., Y. Nakaseko, I. Samejima, K. Kumada, H. Yamada, D. Michaelson, and M. Yanagida. 1996. 20S cyclosome complex formation and proteolytic activity inhibited by the CAMP/PKA pathway. Nature 384: 276-279.

Yoshida, T., T. Toda, and M. Yanagida. 1994. A calcineurin-like gene $\mathrm{ppb}^{+}$in fission yeast: Mutant defects in cytokinesis, cell polarity, mating and spindle pole body positioning. J. Cell Sci. 107: 1725-1735. 


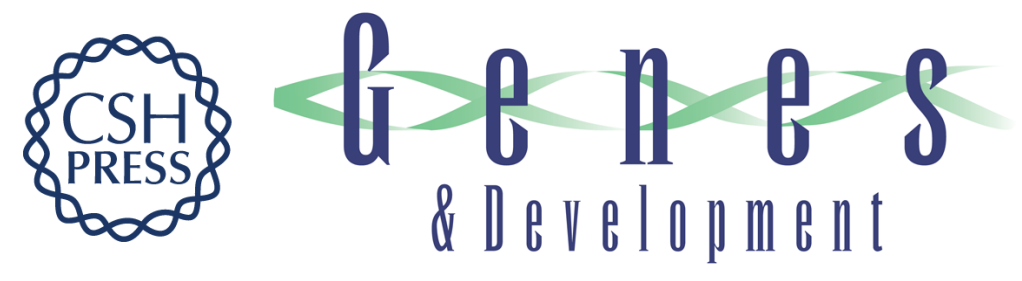

\section{The control of septum formation in fission yeast}

Kathleen L. Gould and Viesturs Simanis

Genes Dev. 1997, 11:

Access the most recent version at doi:10.1101/gad.11.22.2939

References This article cites 72 articles, 37 of which can be accessed free at: http://genesdev.cshlp.org/content/11/22/2939.full.html\#ref-list-1

License

Email Alerting Receive free email alerts when new articles cite this article - sign up in the box at the top Service right corner of the article or click here.

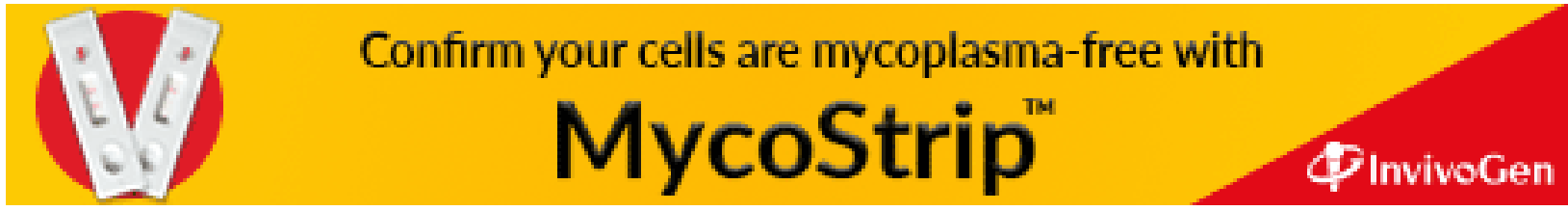

